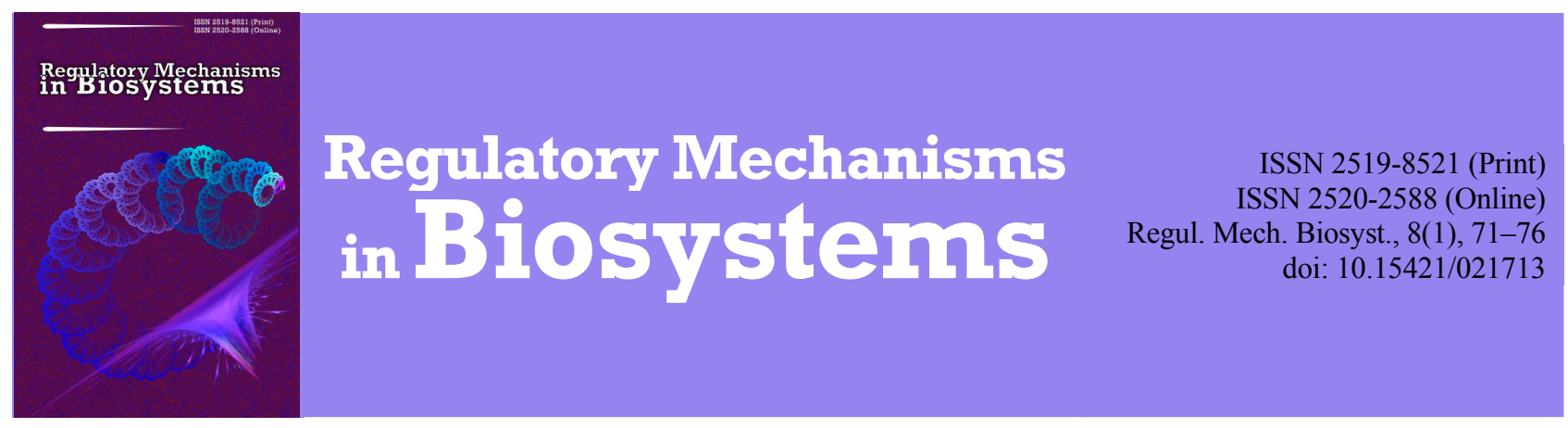

\title{
Features of gas exchange and use of reserve substances in pumpkin seedlings in conditions of skoto- and photomorphogenesis under the influence of gibberellin and chlormequat-chloride
}

\author{
I. V. Poprotska, V. G. Kuryata \\ Vinnytsya State Pedagogical University named after Mykhailo Kotsyubynsky, Vinnytsya, Ukraine
}

Article info

Received 11.01.2017

Received in revised form 13.02.2017

Accepted 15.02.2017

Vinnytsya State Pedagogical University named after Mykhailo Kotsyubynsky, Ostroz'kogo Str., 32, Vinnytsya, 21000, Ukraine Tel.: +38-067-261-98-97 E-mail:i_poprotska@ukr.net

\begin{abstract}
Poprotska, I. V., \& Kuryata, V. G. (2017). Features of gas exchange and use of reserve substances in pumpkin seedlings in conditions of skoto- and photomorphogenesis under the influence of gibberellin and chlormequatchloride. Regulatory Mechanisms in Biosystems, 8(1), 71-76. doi: 10.15421/021713

We investigated the effect of gibberellin and the antigibberellic agent chlormequat-chloride on gas exchange and use of reserve substances in pumpkin seedlings during germination in the light and in the dark. We established that an artificial strengthening or growth inhibition of pumpkin seedlings in conditions of skotomorphogenesis caused an increase in of respiration intensity. Gibberellin treatment increased the proportion of assimilation processes in carbon dioxide gas exchange of seedlings, and growth inhibition by retardant caused an increase in respiratory costs when the nutrition type switches in the light from heterotrophic to autotrophic. The formation by seedlings of the demand for reserve assimilates from cotyledons was largely determined by change of activity of subapical meristems, which is manifested in the acceleration of seed germination, enhancing of histogenesis for the actions of gibberellin and in the weakening of these processes under the influence of retardants. Reserve substances used both oil and nitrogencontaining compounds. The content of protein nitrogen in pumpkin cotyledons decreased more in the light than in the dark, moreover growth inhibition by the retardant slowed down and growth increase by gibberellin accelerated this process both in conditions of photomorphogenesis and skotomorphogenesis.
\end{abstract}

Keywords: Cucurbita pepo L.; source-sink system; retardants; hormonal regulation; seed germination

\section{Introduction}

In modern plant physiology the regulation of "source-sink" relations is seen as the highest level in the hierarchy of processes for the operation of a plant as a whole system. Regulation of these relations, as a system of redistribution of assimilates between organs and tissues of plants during ontogenesis, may be carried out at all levels of organization of a plant organism with the participation of different regulatory mechanisms (Ljung et al., 2015; Savage et al., 2015; Sugiura et al., 2015; Bonelli et al., 2016). The term assimilates means the different compounds of carbon assimilated by the plant during photosynthesis, especially transport and reserve form of carbohydrates, which are the basis of energy and metabolic processes and the "building material" in the growth and development processes (Kiriziy et al., 2014). The issue of recycling and redistribution of substances of other origin (lipids and nitrogencontaining compounds), that are temporarily deposited in reserve organs on germination of seeds and formation of seedling tissues under conditions of the varying tension of "source-sink" relations and of the effect of light and darkness to these processes have been much less studied.

The basic law of "donor - acceptor" relations (the concept of "source-sink") as a system of redistribution of assimilates between organs and tissues of plants during ontogenesis has been studied mainly in the analysis of the ratio of growth and photosynthesis intensity where the growth acts as the main acceptor, and photosynthesis as a donor of assimilates (Rogach and Rogach, 2015; Yu et al., 2015; Kuryata et al., 2016; Rogach et al., 2016). However, the role of interim deposition of plastic materials, features of utilization of reserve compounds of different chemical nature in the heterotrophic growth period (germination), the initial stages of the photosynthetic apparatus formation and switching connections in the "source-sink" system have been insufficiently studied (Kuryata and Kiriziy, 2008). For the study of the features of assimilate redistribution in plants, a treatment of organs by exogenous hormones is widely applied, which allows one to simulate varying degrees of tension in the "source-sink" system. However, the drawback of this approach is obvious, because the treatment of a plant by any phytohormone leads to changes in synthesis and metabolism of all the others, which can cause changes in morphological and physiological programmes. In this connection, research on such a plan should be supplemented with a reverse approach - the treatment of plants by inhibitors of action of a separate phytohormone followed by comparison of the effect of action of the hormone and its inhibitors.

Light as one of the main environmental factors not only provides autotrophic nutrition but also activates the photomorphogenesis programme through the photoreceptor system (Kutschera and Briggs, 2013; Wu, 2014; De Wit and Pierik, 2016; VanHook, 2016). It provides the deetiolation, the differentiation of chloroplasts, the formation of leaf plates and as a result - the transition to autotrophic nutrition.

It is known that the development of plants in the light (photomorphogenesis) and in the dark (skotomorphogenesis) is characterrized by differences in the rate of growth of various organs, which means that under these conditions a different request is formed for deposited assimilates and changes the intensity of their outflows 
from storage organs, so varying degrees of a tension of "sourcesink" system in plants are created. On the other hand, we know that phytohormones are included into the system of photic signal transduction (Hornitschek et al., 2012; Humplík et al., 2015). In particular, the action of light changes metabolism and sensitivity to gibberellins in plants (Golovatskaya and Karnachuk, 2007; Zhang et al., 2014). It is known that the speed of stem growth depends on the meristematic activity of the subapical zone, which is largely controlled by gibberellins (Minguet et al., 2014; Hedden and Thomas, 2016).

Modern plant physiology has the means of "exclusion" of gibberellin from this process, in particular by treatment with retardants - the gibberellic antagonists that either block the synthesis of this group of phytohormones or block the formation of the hormone-receptor complex, which is the functioning of the synthesized gibberellin (Kuryata, 2009; Sang-Kuk and Hak-Yoon, 2014). Thus, although retardants lead to significant morphological changes in the ontogeny of plants (Ramburan and Greenfield, 2007; Kumar et al., 2012; Matysiak and Kaczmarek, 2013; Wang et al., 2016), features of their impact on skoto- and photomorphogenesis in plants remain almost unexplored. Thus, an important aspect of theoretical study of the functioning of the system "assimilates depot - growth" is the comparison of the effects of gibberellin and various groups of retardants in the light and in the dark as factors that act in opposite ways on the growth processes, and therefore on the attractive potential of acceptor.

Changes in the nature of the "source-sink" relations during the transition from the heterotrophic to autotrophic nutrition phase of a plant are best studied using the cotyledon leaves of plants, because the source (cotyledon) and sink (cotyledon leaf) are represented by one organ and separated only in time. It should be noted that the ratio of photosynthesis and respiration under the influence of gibberellin and retardants during germination have been insufficiently studied. It is also known that the different types of reserve substances act as a buffer between the photosynthesis as a "source" of assimilates and growth of a structural substance of the vegetative, storing and reproductive organs as a "sink" of assimilates, which determines some independence of growth processes from the photosynthesis, particularly during germination (Kuryata and Kiriziy, 2008). At the same time, the effect of light and gibberellins on the specifics of recycling of plastic substances which are deposited in cotyledons, remains practically unexplored.

In this connection, the aim of our study was to investigate anatomical and histological changes of seedlings, features of gas exchange and use of reserve compounds in pumpkin cotyledons during exit from dormancy in conditions of photo- and skotomorphogenesis influenced by gibberellin and the antigiberrelic agent chlormequat-chloride.

\section{Materials and methods}

Pumpkin seeds of the variety Mozoliyivskyy 15 in different variants of the experiment were soaked in solutions of preparations gibberellic acid $\left(\mathrm{GA}_{3}, 150 \mathrm{mg} / \mathrm{l}\right)$ and chlormequat-chloride $(0.25 \%$ aquatic solution) during the day and then were planted in a cuvette filled with wet sand. The control option was germinated in distilled water. The seeds were germinated in diffused light and in the dark at room temperature. Biological replication was fivefold.

On the 12th day of germination after straightening of the hypocotyl loop, greening and disclosure of cotyledonary leaves, we determined the utilization coefficient of reserve substances in seeds as the ratio of total dry weight of hypocotyls and roots to the dry matter weight of the whole plant. Analytical replication was fivefold.

For anatomical studies, the pumpkin seedlings were fixed in a mixture of equal parts of ethanol, glycerine and water with addition of $1 \%$ of formalin. The anatomical structure of the pumpkin hypocotyls was explored in cross sections of their middle part. The linear dimensions of the cells was measured under a microscope by using the eyepiece micrometer MOV-1-15. Analytical replication of anatomical research was twentyfold. The intensity of carbon dioxide gas exchange in the pumpkin seedlings was measured by using an infrared optical-acoustic gas analyzer HYAM-5M. For this purpose, the cuvette with seedlings was placed in a sealed desiccator which was purged with air at a speed of $21 / \mathrm{min}$. In determining the darkness respiration the desiccator was covered with black cloth, and for measuring the intensity of photosynthesis in seedlings which were grown in the light the desiccator was lightened an incandescent lamp CG-2000 through a water filter. Radiant flux density was $200 \mathrm{w} / \mathrm{m}^{2}$, the chamber temperature $25^{\circ} \mathrm{C}$. Analytical replication was fivefold.

The dry milled material of cotyledonary leaves and dry seeds were extracted in the Soxhlet apparatus to determine the oil content. The residue after extraction was analyzed for the content of total, protein and non-protein nitrogen by the Kjeldahl method (Bala et al., 2013). Analytical replication was fivefold.

The research results were processed statistically using the programme Statistica 6.0 (StatSoft Inc., USA). The tables and illustrations contain the arithmetic mean values and their standard errors.

\section{Results}

It is known that light controls not only the process of photosynthesis (the donor function), but also the morphophysiological parameters of plants with a definite hierarchical structure of acceptors (Franklin, 2016). Light changes the realization of plants' development programmes, which can be traced in changes in the speed and duration of plants' growth both on the level of the plant as a whole and and on the level of their separate parts (root, epycotyl, hypocotyl, leaf). These changes are realized through the restructuring of the hormonal complex. Phytohormones are included in the light signal transduction because many of the development reactions of plants which are controlled by light also react to the action on plants by hormones (Golovatskaya and Karnachuk, 2007). Results of genetic analysis of mutations of gibberellins and phytochromes indicate an interaction between these signaling systems under certain physiological conditions.

Our results show that plants that grew in the dark developed on the skotomorphogenesis model. They are characterized by longer hypocotyls, the presence of a hypocotyl loop and the yellow colour of the cotyledonary leaves. In the light, plants developed on the photomorphogenesis model: the hypocotyls were shorter, the hypocotyl loop straightened, the cotyledonary leaves grew and acquired an intense green colour (Figure 1).

We have previously found that the growth of pumpkin seedlings was suppressed in the light, but the treatment of seedlings by gibberellic acid eliminated the effect caused by light. The growth inhibitory effect of light intensified in conditions of reduction of gibberellin synthesis under the action of the retardant, this indicates that gibberellins are the active modifiers of the photoreceptor system in plants (Kuryata and Kiriziy, 2008). Similar conclusions have been made by other authors studying the interaction of light at different wavelengths and phytohormones in the processes of skoto- and photomorphogenesis of bean plants (Golovatskaya and Karnachuk, 2007).

An important role in forming a "request" for assimilates is played by the processes of organ- and histogenesis because differentiation of various tissues of the developing organ requires the different costs of reserve metabolites. Analysis of the the anatomical structure of pumpkin seedlings shows that in both conditions of skoto- and photomorphogenesis the number of fibrovascular bundles in seedlings is almost unchanged. However, all the anatomical elements of structure differed in their larger dimensions with seedlings developed in the dark (Table 1). This applies to linear dimensions of epidermal cells, collenchyma (in a cross section), the diameter and length of parenchyma cells. Thus, in conditions of skotomorphogenesis the increasing of growth intensity accompanied by formation of larger anatomical elements of the primary structure and the use of gibberellin increased plant growth in the dark and eliminated the growth inhibiting effect of light in conditions of photomorphogenesis. 
Our results indicate the significant effect of the gibberellin and retardant on germination and intensity of use of reserve compounds in the pumpkin seeds' cotyledons. Determination of the utilization coefficient of reserve substances of seeds (the ratio of the total dry weight of hypocotyls and root to dry weight of the whole plant) in seedlings that grew in the light showed that at the moment of full disclosure of cotyledonary leaves (the 12th day of germination) the greatest value of this indicator was influenced by $\mathrm{GA}_{3}-22.2 \%$, and the action of the chlormequat-chloride decreased it to $13.9 \%$ compared to the control, where it was $18.3 \%$. In seedlings that grew in the dark, use of the reserve substances proceeded more rapidly. Thus, application of chlormequat-chloride caused a decrease in the utilization coefficient of reserve substances in seeds compared to the control and gibberellin. Similar results for use of the reserve compounds of cotelydons during germination of bean seeds in the light and in the dark have also been obtained by other authors (Golovatskaya and Karnachuk, 2007). It is common knowledge that one of the most important functions of gibberellins in the stimulation of the seed germination process in cereals is the ability to stimulate an allocation the $\alpha$-amylase from the germ to the endosperm, which leads to splitting of starch grains. It should be noted that the features of regulation by retardants and gibberellins of germination of seeds containing as the main reserve substance not starch but other compounds (lipids, proteins and other polysaccharides) have been poorly studied.

The results indicate that application of gibberellin and chlormequat-chloride greatly influenced the character of use of the cotyledon's reserve substances. Germination characterized by intensive use of oil as the main reserve substance, and the light and used preparations influenced this process. In dry seeds the oil content was $52.7 \pm$ $0.28 \%$. On the 12 th day of germination the largest reserve of oil remained in the cotyledonary leaves of the photomorphic plants under the action of chlormequat-chloride, which is clearly correlated with the least intense pace of seedling growth in this variant both in the light and in the dark (Table 2).

\section{Table 1}

Effect of gibberellin and retardants on the anatomical structure of pumpkin hypocotyls, variety Mozoliyivskyy 15 , in conditions of skoto- and photomorphogenesis $(n=20)$

\begin{tabular}{|c|c|c|c|c|c|c|}
\hline \multirow[b]{2}{*}{ Index } & \multicolumn{3}{|c|}{ Light } & \multicolumn{3}{|c|}{ Dark } \\
\hline & $\mathrm{GA}_{3}$ & control & $\begin{array}{l}\text { chlormequat- } \\
\text { chloride }\end{array}$ & $\mathrm{GA}_{3}$ & control & $\begin{array}{l}\text { chlormequat- } \\
\text { chloride }\end{array}$ \\
\hline Length of the epidermal cells, $\mu \mathrm{m}$ & $17.3 \pm 1.2^{*}$ & $10.2 \pm 0.4$ & $11.7 \pm 0.8$ & $19.6 \pm 1.6^{*}$ & $15.7 \pm 0.4$ & $12.6 \pm 1.1^{*}$ \\
\hline Width of the epidermal cells, $\mu \mathrm{m}$ & $11.6 \pm 1.1^{*}$ & $8.4 \pm 0.9$ & $7.8 \pm 0.9$ & $9.6 \pm 0.7$ & $9.5 \pm 1.2$ & $8.9 \pm 0.9$ \\
\hline Diameter of the parenchyma cells, $\mu \mathrm{m}$ & $64.7 \pm 1.6^{*}$ & $54.5 \pm 1.3$ & $45.5 \pm 1.5^{*}$ & $84.0 \pm 1.8^{*}$ & $75.9 \pm 2.1$ & $58.4 \pm 1.8^{*}$ \\
\hline Height of the parenchyma cells, $\mu \mathrm{m}$ & $430.5 \pm 26.7^{*}$ & $262.9 \pm 13.4$ & $186.9 \pm 14.1^{*}$ & $543.4 \pm 22.6$ & $484.8 \pm 21.4$ & $182.4 \pm 13.3^{*}$ \\
\hline $\begin{array}{l}\text { Volume of the parenchyma cells, } \\
\text { thousands } \mu \mathrm{m}^{3}\end{array}$ & $1414.7 \pm 74.1^{*}$ & $594.6 \pm 32.3$ & $265.8 \pm 24.7^{*}$ & $3009.9 \pm 64.8^{*}$ & $2198.2 \pm 49.7$ & $363.8 \pm 24.9 *$ \\
\hline Length of the collenchyma cells, $\mu \mathrm{m}$ & $29.7 \pm 1.1^{*}$ & $24.2 \pm 1.2$ & $26.4 \pm 0.9$ & $29.0 \pm 0.8^{*}$ & $25.9 \pm 0.8$ & $22.1 \pm 1.0^{*}$ \\
\hline Width of the collenchyma cells, $\mu \mathrm{m}$ & $18.3 \pm 0.8^{*}$ & $15.0 \pm 0.8$ & $13.4 \pm 0.8$ & $24.3 \pm 0.5^{*}$ & $21.3 \pm 0.6$ & $22.4 \pm 0.5$ \\
\hline Number of the fibrovascular bundles & $10.5 \pm 0.2$ & $10.8 \pm 0.4$ & $11.3 \pm 0.6$ & $10.7 \pm 0.4$ & $9.5 \pm 0.5$ & $10.4 \pm 0.7$ \\
\hline
\end{tabular}

Notes: the $12 \mathrm{~h}$ day of germination; $\mathrm{GA}_{3}-150 \mathrm{mg} / \mathrm{l}$; chlormequat-chloride $-0.25 \%$; * - significant difference at $\mathrm{P}<0.05$.

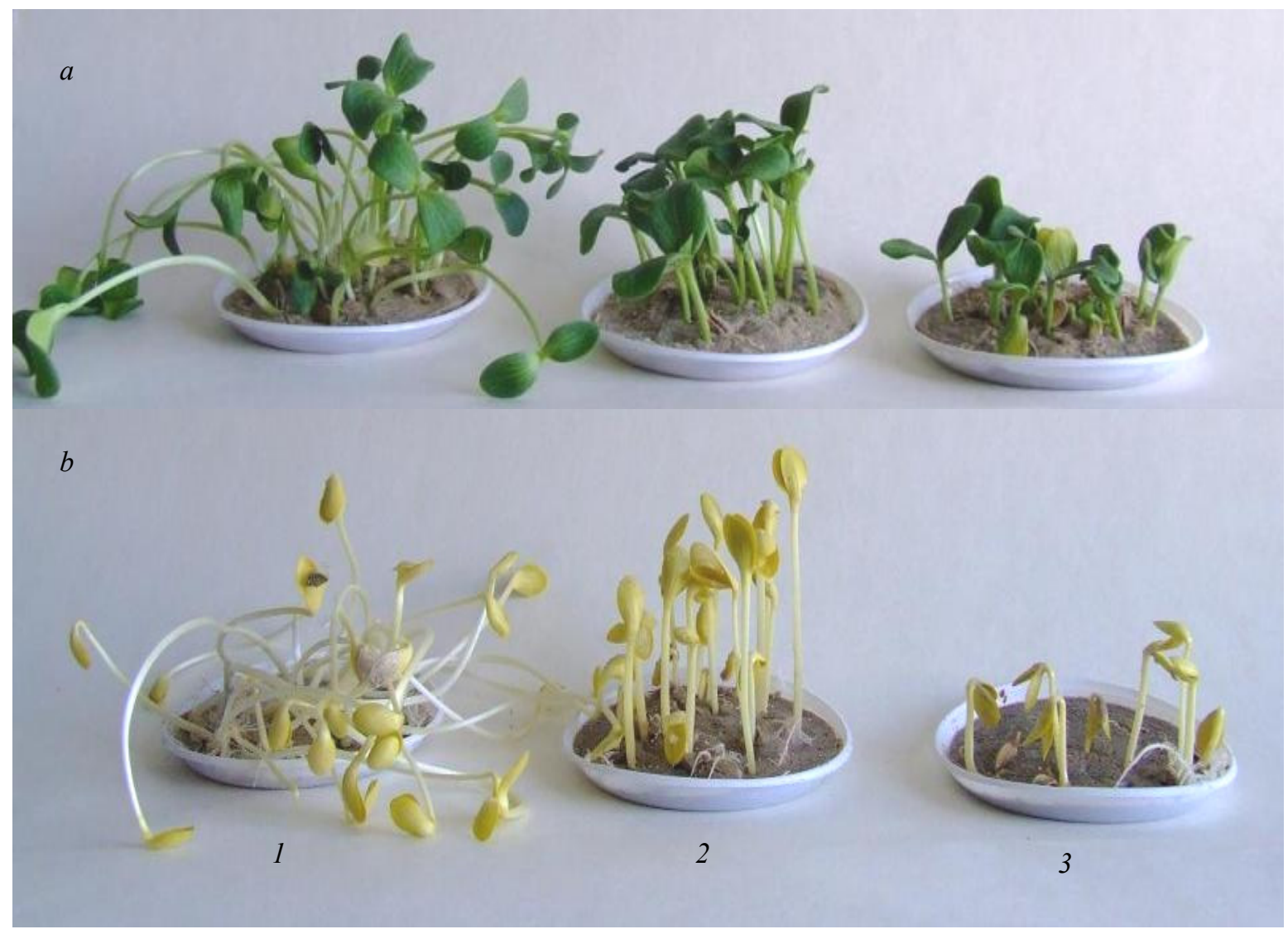

Figure 1. The action of gibberellin and chlormequate-chloride on the germination of pumpkin seeds, variety Mozoliyivskyy 15 , in the light $(a)$ and in the dark $(b): 1$ - GA3 $(150 \mathrm{mg} / \mathrm{l}) ; 2$ - control; 3 - chlormequate-chloride $(0.25 \%)$; the $12 \mathrm{~h}$ day of germination 
We have previously found that in conditions of skoto- and photomorphogenesis there are certain changes in the HFA ratio in the oil of cotyledonary leaves (Kutyata and Kiriziy, 2008). In particular, in the light in all variants of the experiment the content of stearic acid increased as compared to the oil of dry seeds 1 , and in the dark such an increase was noted only in the variant with GA3, in the control and in the variant with retardants the content of this acid did not differ from the oil of dry seeds. In conditions of skotomorphogenesis the content of the unsaturated HFA (oleic and linoleic) increased especially significantly. However, the increased growth of seedlings under the influence of gibberellin $\left(\mathrm{GA}_{3}\right)$ was not accompanied by a more intensive use of oil, its content in this variant was higher than in the control. In our view, this indicates that under the action of phytohormones increased growth is determined not only by fast utilization of lipids, but also by possible intensified hydrolysis of other reserve substances of cotyledons - the nitrogen-containing compounds.

\section{Table 2}

The oil content in germinating pumpkin seeds cotyledons, variety Mozoliyivskyy 15, under the influence of gibberellin and chlormequat-chloride in conditions of photo- and skotomorphogenesis ( $\%$ per weight of dry matter, $n=5$ )

\begin{tabular}{lcc}
\hline Variant of experiment & Photomorphogenesis & Skotomorphogenesis \\
\hline Control & $8.8 \pm 0.2$ & $7.6 \pm 0.1$ \\
$\mathrm{GA}_{3}$ & $12.2 \pm 0.3^{*}$ & $11.6 \pm 0.2^{*}$ \\
Chlormequat-chloride & $22.4 \pm 0.3^{*}$ & $15.5 \pm 0.4^{*}$ \\
\hline
\end{tabular}

Notes: the $12 \mathrm{~h}$ day of germination; $\mathrm{GA}_{3}-150 \mathrm{mg} / \mathrm{l}$; chlormequat-chloride $0.25 \% ; *$ - significant difference at $\mathrm{P}<0.05$.

The integrity of a plant organism is based on interaction of the organs and active exchange of organic and mineral substances between them. However, the nature of income and redistribution of nitrogencontaining compounds between plant organs with changes in the source-sink relations during heterotrophic development in general and under the influence of gibberellin and retardants in particular remains largely unexplored. Since retardants are the modifiers of hormonal and inhibitory balance in plants, here the question arises of changes in the income and redistribution between organs of plant nitrogen compounds under the influence of this group of preparations. In our opinion, for the better understanding of the nature of changes in source-sink relations under the influence of retardants, it was expedient to analyze the dynamics of content of different forms of nitrogen and their proportion in different stages of growth and development with an artificial change of the acceptor activity for the actions of gibberellin and its antagonist (Table 3). The use of cotyledonary leaves as a research model to study the question of utilization of reserve nitrogenous compounds allows one to analyze the translocation of only reserve forms of nitrogenous compounds and exclude the "new" nitrogen, which comes from the root system by mineral nutrition.

The analysis of our data indicates that under conditions of photo- and skotomorphogenesis there was a significant outflow of nitrogen from cotyledons to seedlings, and the content of total and protein nitrogen in defatted material of cotyledonary leaves was significantly different, in particular it was lower during the development of seedlings in the light (Table 3 ). In our view, this indicates a more intensive use of cotyledon protein for growth processes during formation of seedling structures in conditions of photomorphogenesis.
The different rates of growth processes under action of gibberellin and retardant were accompanied by a different intensity of outflow of nitrogen-containing compounds from the cotyledons. In particular, in the light the least protein nitrogen remained in the variant of gibberellin, and the mostly - in the variant with the use of its antagonist chlormequat-chloride. Upon germination in the dark for actions of the retardant the protein nitrogen was used less intensively. In the control variant and in the variant with application of gibberellin the intensity of use of protein nitrogen was the same, but the decrease of total nitrogen in cotyledons influenced by the phytohormone occurred more intensively at the expense of the non-protein fraction.

\section{Table 3}

The content of different forms of nitrogen in germinating pumpkin seeds cotyledons, variety Mozoliyivskyy 15, under the influence of gibberellin and chlormequat-chloride in conditions of photoand skotomorphogenesis ( $\%$ per weight of dry matter, $n=5)$

\begin{tabular}{lccc}
\hline Variant of experiment & $\begin{array}{c}\text { Total } \\
\text { nitrogen }\end{array}$ & $\begin{array}{c}\text { Protein } \\
\text { nitrogen }\end{array}$ & $\begin{array}{c}\text { Non-protein } \\
\text { nitrogen }\end{array}$ \\
\hline Dry seeds & $11.08 \pm 0.02$ & $10.40 \pm 0.01$ & $0.68 \pm 0.01$ \\
& \multicolumn{3}{c}{ Photomorphogenesis } \\
Control & $6.05 \pm 0.01$ & $4.04 \pm 0.01$ & $2.01 \pm 0.04$ \\
$\mathrm{GA}_{3}$ & $5.99 \pm 0.02^{*}$ & $3.68 \pm 0.01^{*}$ & $2.31 \pm 0.03^{*}$ \\
Chlormequat-chloride & $7.13 \pm 0.02^{*}$ & $4.94 \pm 0.04^{*}$ & $2.19 \pm 0.02^{*}$ \\
& \multicolumn{3}{c}{ Skotomorphogenesis } \\
Control & $6.91 \pm 0.01$ & $4.75 \pm 0.01$ & $2.16 \pm 0.05$ \\
GA $_{3}$ & $6.73 \pm 0.03^{*}$ & $4.76 \pm 0.01$ & $1.97 \pm 0.02^{*}$ \\
Chlormequat-chloride & $7.16 \pm 0.01^{*}$ & $5.09 \pm 0.02^{*}$ & $2.07 \pm 0.01$ \\
\hline
\end{tabular}

Notes: see Table 2.

The results obtained also show that the use of gibberellin and the antigiberrelic agent chlormequat-chloride under conditions of photoand skotomorphogenesis influenced significantly the gas exchange of seedlings (Table 4). At present, respiration is seen as a powerful metabolic acceptor of carbon, and the total respiratory costs may reach $60 \%$ of the carbon assimilated in photosynthesis (Kuryata, 2009). The ratio of respiration/photosynthesis largely characterizes the tension of source-sink relations in plants, but the scale of respiratory costs compared with the true photosynthesis during the transition to other levels of source-sink relations has not been completely clarified.

Under conditions of skotomorphogenesis, the control variant was marked by the lowest intensity of dark respiration, and under the action of gibberellin and its antagonist chlormequat-chloride the intensity of respiration increased. In the seedlings that grew in the light, the highest intensity of respiration was observed in the variant with chlormequatchloride, and the lowest - in the variant with gibberellin. Generally, in all variants of the experiment the dark respiration intensity was lower in seedlings which passed on the light from heterotrophic to autotrophic nutrition than in seedlings, grown in the dark (Table 4). Thus, a modification of regulatory relations in the source-sink system "depot of assimilates - growth" in the early development of seedlings by using exogenous gibberellin and retardant chlormequat-chloride leads to changes in morphogenesis and growth rate, which affects the intensity of reserve compounds' use, respiration and photosynthesis during the transition to autotrophic nutrition. In the dark and using gibberellin the request for reserve substance increases, while in the light and with treatment by retardants the acceptor activity of seedlings decreases.

\section{Table 4}

Intensity of gas exchange of pumpkin seedling, variety Mozoliyivskyy 15 ,

under the influence of gibberellin $\left(\mathrm{GA}_{3}, 150 \mathrm{mg} / \mathrm{l}\right)$ and chlormequat-chloride $(0.25 \%$ solution $)$ under photo- and skotomorphogenesis $\left(\mathrm{mg} \mathrm{CO}_{2} / \mathrm{g}\right.$ of dry matter $\bullet \mathrm{h}$, the $12 \mathrm{~h}$ day of germination, $\mathrm{n}=5$ )

\begin{tabular}{lcccccc}
\hline & \multicolumn{4}{c}{ Photomorphogenesis } & & Skotomorphogenesis \\
\cline { 2 - 7 } Variant of experiment & $\begin{array}{c}\text { utilization coefficient } \\
\text { of reserve substances } \\
\text { of seeds, \% }\end{array}$ & $\begin{array}{c}\text { intensity of } \\
\text { respiration (R) }\end{array}$ & $\begin{array}{c}\text { apparent } \\
\text { photosynthesis }\end{array}$ & $\begin{array}{c}\text { true photosynthesis } \\
(\text { Pg) }\end{array}$ & $\begin{array}{c}\text { R/Pg } \\
\text { utilization coefficient } \\
\text { of reserve substances } \\
\text { of seeds, \% }\end{array}$ & $\begin{array}{c}\text { intensity of } \\
\text { respiration (R) }\end{array}$ \\
\hline Control & $18.30 \pm 0.64$ & $1.70 \pm 0.07$ & $0.95 \pm 0.02$ & $2.65 \pm 0.09$ & 0.59 & $35.9 \pm 0.85$ \\
$\mathrm{GA}_{3}$ & $22.20 \pm 0.35^{*}$ & $1.14 \pm 0.03^{*}$ & $0.81 \pm 0.03^{*}$ & $1.95 \pm 0.06^{*}$ & 0.64 & $38.4 \pm 0.32^{*}$ \\
Chlormequat-chloride $^{13.87 \pm 0.56^{*}}$ & $2.57 \pm 0.08^{*}$ & $0.32 \pm 0.01^{*}$ & $2.89 \pm 0.09$ & $3.00 \pm 0.12^{*}$ \\
\hline
\end{tabular}

Note: * - significant difference at $\mathrm{P}<0.05$. 


\section{Discussion}

It is known that there is a close relationship between the changes in growth characteristics with the action of retardants and the activity of gibberellins. In particular, under the influence of paclobutrazol, chlormequat-chloride and dekstrel a significant decrease was noted in the activity of free gibberellins in raspberry shoots in conditions of growing and field experiments, while the introduction of exogenous gibberellic acid raised significantly their activity in the tissues of the stem (Kuryata, 2009). Our results indicate that gibberellin increased and chlormequat-chloride decreased the linear dimensions and volume of cells of the main parenchyma, but the use of preparations had no effect on the number of fibrovascular bundles in the stem. Thus, gibberellins and the absence of light increase growth processes, and therefore attractive activity in seedlings at the heterotrophic nutrition stage. The use of retardants and the effect of light in this period acts in the opposite way - reduces the intensity of the growth process and therefore the attractive activity of seedlings. Consequently, the formation by seedlings of "a request" for the reserve assimilates from cotyledons is largely determined by changes in subapical meristem activity, which is manifested in the acceleration of seed germination, amplification of histogenesis for the action of gibberellin and weakening of these processes under the influence of the retardant.

Since the growth amplified and the activity of seedlings' meristems intensified under $\mathrm{GA}_{3}$ compared with the action of retardants, it is important to analyze the features of redistribution of reserve substances in the acceptor zone (seedling) in the variants of the experiment in connection with formation of a different request for reserve metabolites. The results obtained for determining the content of different forms of nitrogen and oil in the cotyledons indicate that gibberellins are an important link of the unique regulatory mechanism of mobilization of reserve substances in germinating seeds, regardless of their chemical nature. The level of utilization of nitrogenous compounds from cotyledons was higher with the action of gibberellin. Previously, it was also found that the process of pumpkin seed germination was accompanied not only by use of typical reserve substances of oil crops - reserve oil and nitrogen-containing compounds, but also by a significant restructuring of polysaccharide complex of cell walls. The pentosans of cell walls use as a reserve substance and there is a change of conformation and a partial increase in the molecular weight of pectins. These processes were amplified in conditions of skotomorphogenesis as a result of intensive growth of seedlings in the absence of autotrophic nutrition and, consequently, a deeper utilization of the reserves of the donor plastic substances - the cotyledons (Poprotska, 2014).

Intensity of plant respiration is closely related to the growth processes, usually intensity of respiration is amplified with intensification of growth. The application of retardants allows one to explain clearly the significance of respiration components with the artificial change of donor and acceptor (source and sink) activity because it is possible to simulate this type of disbalance of the donor and acceptor activity in which a request to assimilates of the main acceptor (developing seedlings) is reduced due to inhibition its meristem activity. It must be emphasized that depending on the methodological approaches and the degree of research detail both the separate plant structures (organs, tissues, cells and organelles) and the processes (photosynthesis, respiration, storing, transportation) can act as a donor and as an acceptor. In this, the application of "donor and acceptor" concepts to particular organs or processes is not absolute and depends on the development phase of the separate organ or the whole plant (Kiriziy et al., 2014).

The results obtained permit one to draw the conclusion that gibberellin and its antagonists have opposite effects on respiratory components: stimulation of growth under the action of $\mathrm{GA}_{3}$ is accompanied by increased growth respiration, and support of cell homeostasis under the action of the growth inhibiting preparation chlormequat-chloride provided by increase of maintenance respiration (Kuryata, 2009). In our view, the decrease in the intensity of true photosynthesis per unit weight of dry matter influenced by $\mathrm{GA}_{3}$ com- pared to control can be explained by the lower proportion of the cotyledons' weight compared to the whole plant in this version. At the same time, the respiratory costs $(\mathrm{R} / \mathrm{Pg})$ greatly increased in the variant using chlormequat-chloride. We have previously been suggested that respiration plays the role of "safety valve" by removing the excess of assimilates in the form of $\mathrm{CO}_{2}$ (Kuryata and Kiriziy, 2008). Thus the donor function of cotyledonary leaves of photomorphic plants is limited by the increase of respiratory costs, therefore it decreases the proportion of assimilates that are directed to the needs of organogenesis. The combined use of light, gibberellin and retardants for artificial regulation of tension of source-sink relations in plants can be an effective methodological approach to study of the role of phytohormones and to clarify the features of use of plant reserve compounds in experimental researches of the germination processes.

\section{Conclusions}

In conditions of skotomorphogenesis of pumpkin seedlings an inhibition or intensification of growth caused increase in respiration intensity. When nutrition type in the light was switched from heterotrophic to autotrophic, gibberellin treatment increased the proportion of assimilation processes in carbon dioxide gas exchange of pumpkin seedlings and growth inhibition by the retardant caused an increase in respiratory costs. The formation of a "request" to the reserve assimilates from cotyledons by seedlings is largely determined by changes in activity of subapical meristems, which are manifested in acceleration of seed germination, enhancement of histogenesis for the actions of gibberellin and the weakening of these processes under the influence of retardants. Both oil and nitrogencontaining compounds were used as reserve substances. The content of protein nitrogen in pumpkin cotyledons decreased more in the light than in the dark, and growth inhibition by the retardant slowed down and increasing by gibberellin accelerated this process both in conditions of photo- and skotomorphogenesis.

\section{References}

Bala, M., Gupta, S., Gupta, N. K., \& Sangha, M. K. (2013). Practical in plant physiology and biochemistry. Scientific Publisher, Jodhpur.

Bonelli, L. E., Monzon, J. P., Cerrudo, A., Rizzalli, R. H., \& Andrade, F. H. (2016). Maize grain yield components and source-sink relationship as affected by the delay in sowing date. Field Crops Research, 198, 215-225.

De Wit, M., \& Pierik, R. (2016). Photomorphogenesis and photoreceptors. Canopy Photosynthesis: From Basics to Applications, 42, 171-186.

Franklin, K. A. (2016). Photomorphogenesis: Plants feel blue in the shade. Current Biology, 26(24), R1275-R1276.

Golovatskaya, I. F., \& Karnachuk, R. A. (2007). Dinamika rosta rastenij i soderzhanie endogennyh fitogormonov $\mathrm{v}$ processe skoto- i fotomorfogeneza fasoli [Dynamics of growth and the content of endogenous phytohormones during kidney bean scoto- and photomorphogenesis]. Fiziologija rastenij, 54(3), 461-468 (in Russian).

Hedden, P., \& Thomas, S. G. (2016). The gibberellins. Annual Plant Reviews, 49. John Wiley \& Sons.

Hornitschek, P., Kohnen, M. V., Lorrain, S., Rougemont, J., Ljung, K., LópezVidriero, I., Franco-Zorrilla, J. M., Solano, R., Trevisan, M., Pradervand, S., Xenarios, I., \& Fankhauser, C. (2012). Phytochrome interacting factors 4 and 5 control seedling growth in changing light conditions by directly controlling auxin signaling. The Plant Journal, 71(5), 699-711.

Humplík, J. F., Turečková, V., Fellner, M., \& Bergougnoux, V. (2015). Spatio-temporal changes in endogenous abscisic acid contents during etiolated growth and photomorphogenesis in tomato seedlings. Plant Signaling and Behavior, 10(8), e1039213.

Kiriziy, D. A., Stasyk, O. O., Pryadkina, G. A., \& Shadchyna, T. M. (2014). Fotosintez. T. 2. Assimilyatsiya $\mathrm{CO}_{2}$ i mehanizmy jejyo regulyatsii. Logos, Kiev (in Russian).

Kumar, S., Ghatty, S., Satyanarayana, J., Guha, A., Chaitanya, B., \& Reddy, A. R. (2012). Paclobutrazol treatment as a potential strategy for higher seed and oil yield in field-grown Camelina sativa L. Crantz. BMC Research Notes, 5, 137.

Kuriata, V. G., Rohach, V. V., Rohach, T. I., \& Khranovska, T. V. (2016). The use of antigibberelins with different mechanisms of action on morphogenesis and production process regulation in the plant Solanum 
melongena (Solanaceae). Visnyk of Dnipropetrovsk University. Biology, Ecology, 24(1), 230-234.

Kuryata, V. G. (2009). Retardanty - modyfikatory gormonalnogo statusu roslyn. Fiziologija roslyn: Problemy ta perspektyvy rozvytku. T. 1. Logos, Kyiv (in Ukrainian).

Kuryata, I. V., \& Kiriziy, D. A. (2008). Regulyatsiya donorno-aktseptornyh vidnosyn u systemi depo asymilyativ- rist u prorostkiv garbuza pid vplyvom giberelinu i hlormekvathlorydu za umov skoto- i fotomorfogenezu [Regulation of sourse-sink relations in the system reserve assimilates-growth in cucurbit (Cucurbita pepo L.) under the effect of gibberellin and chlormequate chloride in scoto- and photomorphogenesis conditions]. Fiziologija i biohimija kul'turnih rastenij, 40(5), 448-457 (in Ukrainian).

Kutschera, U., \& Briggs, W. R. (2013). Seedling development in buckwheat and the discovery of the photomorphogenic shade-avoidance response. Plant Biology, 15(6), 931-940.

Ljung, K., Nemhauser, J. L., \& Perata, P. (2015). New mechanistic links between sugar and hormone signalling networks. Current Opinion in Plant Biology, 25, 130-137.

Matysiak, K., \& Kaczmarek, S. (2013). Effect of chlorocholine chloride and triazoles - tebuconazole and flusilazole on winter oilseed rape (Brassica napus var. oleifera L.) in response to the application term and sowing density. Journal of Plant Protection Research, 53(1), 79-88.

Minguet, E. G., Alabadi, D., \& Blázquez, M. A. (2014). Gibberellin implication in plant growth and stress responses. Phytohormones: A Window to Metabolism, Signaling and Biotechnological Applications, 119-161.

Poprotska, I. V. (2014). Zminy v polisaharydnomu kompleksi klitynnyh stinok sim'yadolej prorostkiv garbuza za riznoyi napruzhenosti donornoaktseptornyh vidnosyn $\mathrm{v}$ protsesi prorostannya [Changes in polysaccharide complex of cell walls of the pumpkin seedlings cotyledons under different level of source-sink relations during germination]. Fiziologiya i Biohimiya Kulturnykh Rastenij, 46(3), 190-195 (in Ukrainian).

Ramburan, S., \& Greenfield, P. L. (2007). Use of ethephon and chlormequat chloride to manage plant height and lodging of irrigatend barley (cv. Puma) when hight rates of $\mathrm{N}$-fertiliser are applied. South African Journal of Plant and Soil, 24(4), 181-187.

Rogach, V. V., \& Rogach, T. I. (2015). Vplyv syntetychnyh stymulyatoriv rostu na morfofiziologichni harakterystyky ta biologichnu produktyvnist' kul'tury kartopli [Influence of synthetic growth stimulators on morphological and physiological characteristics and biological productivity of potato culture]. Visnyk of Dnipropetrovsk University. Biology, Ecology, 23(2), 221-224 (in Ukrainian).

Rogach, V. V., Poprotska, I. V., \& Kuryata, V. G. (2016). Diya giberelinu ta retardantiv na morfogenez, fotosyntetychnyj aparat i produktyvnist' kartopli [Effect of gibberellin and retardants on morphogenesis, photosynthetic apparatus and productivity of the potato]. Visnyk of Dnipropetrovsk University. Biology, Ecology, 24(2), 416-419 (in Ukrainian).

Sang-Kuk, K., \& Hak-Yoon, K. (2014). Effects of gibberellin biosynthetic inhibitors on oil, secoisolaresonolodiglucoside, seed yield and endogenous gibberellin content in flax. Korean Journal of Plant Resources, 27(3), 229-235.

Savage, J. A., Haines, D. F., \& Holbrook, N. M. (2015). The making of giant pumpkins: How selective breeding changed the phloem of Cucurbita maxima from source to sink. Plant, Cell and Environment, 38(8), 1543-1554.

Sugiura, D., Sawakami, K., Kojima, M., Sakakibara, H., Terashima, I., \& Tateno, M. (2014). Roles of gibberellins and cytokinins in regulation of morphological and physiological traits in Polygonum cuspidatum responding to light and nitrogen availabilities. Functional Plant Biology, 42(4), 397-409.

VanHook, A. M. (2016). Rapidly inhibiting ethylene signaling with light. Science Signaling, 9(458), 294.

Wang, Y., Gu, W., Xie, T., Li, L., Sun, Y., Zhang, H., Li, J., \& Wei, S. (2016). Mixed compound of DCPTA and CCC increases maize yield by improving plant morphology and upregulating photosynthetic capacity and antioxidants. PLoS One, 11(2), e0149404.

$\mathrm{Wu}, \mathrm{S} .-\mathrm{H}$. (2014). Gene expression regulation in photomorphogenesis from the perspective of the central dogma. Annual Review of Plant Biology, 65, 311-333.

Yu, S. M., Lo, S. F., \& Ho, T. D. (2015). Source - sink communication: Regulated by hormone, nutrient, and stress cross-signaling. Trends in Plant Science, 20(12), 844-857.

Zhang, D., Jing, Y., Jiang, Z., \& Lin, R. (2014). The chromatin-remodeling factor PICKLE integrates brassinosteroid and gibberellin signaling during skotomorphogenic growth in Arabidopsis. The Plant Cell, 26(6), 2472-2485. 